\title{
Free Fatty Acid Receptor 1
}

National Cancer Institute

\section{Source}

National Cancer Institute. Free Fatty Acid Receptor 1. NCI Thesaurus. Code C101749.

Free fatty acid receptor 1 (300 aa, $\sim 31 \mathrm{kDa}$ ) is encoded by the human FFAR1 gene. This protein plays a role in fatty acid-dependent receptor signaling. 